\title{
Analisis Hadis-Hadis yang Disampaikan Mubaligh di Masjid Agung Baitul Makmur Rejang Lebong
}

\author{
Busra Febriyarni \\ Dosen Sekolah Tinggi Agama Islam Negeri Curup \\ e-mail: bundabusra@gmail.com
}

\begin{abstract}
A Research of living hadis that researcher did this time was in the Great Mosque Baitul Makmur Rejang Lebong. It consideredthat this mosque is a government and largest mosque in Curup City Rejang Lebong. Every shubuh there is always taushiyah there. As comparisons, the researcher also took the Aljihad Mosque and Nurul Huda Curup Mosque. A complete facts of the hadis submitted by the preacher from the 3 mosques. The researcher took 1 month of Ramadan for the research. How are the traditions used by theologians in preaching some hadis, whether they are in accordance with the standard practice of a hadis, that is shabih and hasan or still in dhaif and maudhu category. If qualified shabih and hasan then they should be practiced, but if they qualified dha'if and maudhu so then they must be abandoned. Majority of preachers in these three mosques in particular have delivered some hadis qualified maqbul. Minorities of them still present some hadis that qualified mardud or rejected.
\end{abstract}

Key Words: Mubaligh; Maqbul; Mardud

\begin{abstract}
Abstrak
Penelitian living hadis yang peneliti lakukan kali ini adalah di masjid Agung Baitul Makmur Rejang Lebong mengingat masjid ini adalah masjid pemerintah dan terbesar di Kota Curup Rejang Lebong yang setiap shubuh selalu ada taushiyah. Sebagai perbandingan peneliti juga mengambil mesjid Aljihad dan Mesjid Nurul Huda Curup. Gambaran yang lengkap dari hadis-hadis yang disampaikan mubaligh dari 3 mesjid tersebut, peneliti mengambil waktu selama 1 bulan Ramadhan. Bagaimana sesungguhnya hadis-hadis yang dipakai ulama dalam berdakwah, yang akhirnya apakah sudah sesuai standar pengamalan sebuah hadis yaitu shabih dan hasan atau masih dalam kategori dhaif dan maudhu'Jika berkualitas shahih dan hasan maka hadis-hadis tersebut harus diamalkan, tetapi jika berkualitas dha'if dan maudhu' maka harus ditinggalkan. Mayoritas mubaligh di tiga mesjid ini khususnya sudah menyampaikan hadis-hadis yang berkualitas maqbul. Minoritas dari mereka masih ada yang menyampaikan hadis hadis yang berkualitas mardud atau ditolak.
\end{abstract}

Kata Kunci: Mubaligh; Maqbul; Mardud 
40 |Jurnal Dakwah dan Komunikasi, Vol. 3, No. 1, 2018

\section{Pendahuluan}

Penelitian Al-Qur'an dan Hadis yang marak dilakukan oleh para peneliti, pencinta dan masyarakat hari ini adalah wujud dari perkembangan ilmu Al-qur'an dan Hadis di era sekarang. Dalam lintasan sejarah Islam, bahkan dalam era yang sangat dini praktek memperlakukan Al-Qur'an atau unit-unit tertentu dari Al-Qur'an sehingga bermakna dalam kehidupan praktis umat Islam pada dasarnya sudah terjadi ketika Nabi Muhammad masih hidup, sebuah masa yang paling baik bagi umat Islam, masa dimana semua perilaku umat masih terbimbing wahyu lewat Nabi secara langsung. Living Qur'an yang sebenarnya bermula dari fenomena Qur'an in everyday life, yakni makna-makna dan fungsi Al-Qur'an yang riil difahami dan dialami masyarakat muslim, belum menjadi objek studi bagi ilmu-ilmu Al-Qur'an konvensional (klasik). Yang dimaksud dengan living Qur'an dalam konteks ini adalah kajian atau penelitian ilmiah tentang berbagai peristiwa sosial terkait dengan kehadiran Al-Qur'an atau keberadaan Al-Qur'an disebuah komunitas muslim tertentu.

Living hadis adalah sunah atau hadis yang hidup dimana hadis ini berangkat dari ijtihad yang disepakati bersama dalam suatu komunitas muslim yang didalamnya termasuk ijma' dan ijtihad para ulama' dan tokoh agama di dalam aktivitasnya. Living hadis merupakan suatu pemahaman hadis yang berada pada level praksis lapangan. Apa yang dijalankan di masyarakat tidak sama dengan misi yang diemban Nabi Muhammad. Sebagaimana digambarkan oleh Rumi tentang sejumlah orang yang menilai gajah dalam kegelapan. Asas living hadis dapat dilihat dalam tiga bentuk, yaitu tulisan, lisan, dan praktik. Ketiga model dan bentuk living hadis tersebut satu dengan yang lainnya sangat berhubungan. ${ }^{1}$

Penelitian living Qur'an dan hadis sarat akan nilai-nilai kehidupan. Tidak hanya itu tetapi bagaimana kedua barometer kehidupan ini semakin menjiwa dalam realitas kehidupan masyarakat. Hal ini didasarkan kepada kecintaan yang mendalam kepada Rasulullah SAW, ketika riwayat beliau telah terkodifilasi dengan baik dan sistimatis, maka tugas kita selanjutnya adalah mendalami, mengkaji dan mengamalkan secara kaffah dalam keseharian.

Dalam hal ini penulis merasa tergugah dan terpanggil untuk meneliti tentang living hadis dalam kehidupan terutama dalam penyampaian dakwah di tengah masyarakat. Para mubaligh dalam menyampaikan dakwahnya selalu dikuatkan dengan dalil Al-Quran dan Hadis Rasulullah SAW., hanya terkadang hadis-hadis yang disampaikan masih variatif, adakalanya sudah berkategori shabih, hasan, bahkan masih banyak yang dhaif juga maudhu'. ${ }^{2}$ Padahal dalam kriteria hadis yang bisa diterima atau

${ }^{1}$ Sahiron Syamsuddin editor, Metodologi Penelitian Living Quran Hadis, Yogyakarta: TH Press, 2007, h. Pengantar xiii

${ }^{2}$ Hadis shabib adalah hadis yang memenuhi lima persyaratan, yaitu: 1) sanadnya bersambung, 2) perawinya 'adil, 3) perawinya dhabith, 4) tidak mengandung syadz atau kejanggalan dan 5) tidak mengandung cacat atau 'illat. Lihat Ibn Shalah, 'ulum al-Hadis, Medinah; Maktabah al-Ilmiyyah, 1981, hlm 10. Hadis Hasan adalah Hadis yang kualitasnya setingkat di bawah hadis shabih. Perbedaan tingkat kualitas ini terletak dari segi ke-dhabith-an perawinya, perawi hadis shabih terujud dalam diri mereka kesepurnaan dhabith, sedangkan pada perawi hadis hasan kualitasnya kurang sempurna. Lihat 'Ajjaj al-Khatib, Ushul al-Hadis 'Ulumub wa Musthalahuh, 
diamalkan adalah yang berkualitas shahih dan hasan. Sementara untuk hadis dhaif maka ulama tidak membolehkan berhujjah dengannya jika dhaif-nya berat, tetapi untuk dhaif yang ringan masih dibolehkan dalam hal motivasi melakukan kebaikan (tidak dalam hal ibadah wajib) hanya persoalan-persoalan keutamaan amal-amal sunnah harian (fadhail 'amal). Sementara untuk hadis maudhu' tidak boleh dijadikan bujjab karena ia bukan bersumber dari Nabi Muhammad SAW., tetapi dari orang-orang yang tidak bertanggung jawab yang ingin mengacaukan dan menghancurkan pemahaman umat Islam.

Penelitian living hadis yang peneliti lakukan kali ini adalah di masjid Agung Baitul Makmur Rejang Lebong mengingat masjid ini adalah masjid pemerintah dan terbesar di Kota Curup Rejang Lebong yang setiap shubuh selalu ada taushiyah. Sebagai perbandingan peneliti juga mengambil mesjid Aljihad dan Mesjid Nurul huda Curup. Gambaran yang lengkap dari hadis-hadis yang disampaikan mubaligh dari 3 mesjid tersebut, peneliti mengambil waktu selama 1 bulan Ramadhan. Bagaimana sesungguhnya hadis-hadis yang dipakai ulama dalam berdakwah, yang akhirnya apakah sudah sesuai standar pengamalan sebuah hadis yaitu shabih dan hasan atau masih dalam kategori dhaif dan maudhu'.

Jika berkualitas shahih dan hasan maka hadis-hadis tersebut harus diamalkan, tetapi jika berkualitas dha'if dan maudhu' maka harus ditinggalkan.

\section{Mesjid Agung Baitul Makmur Curup}

Penelitian ini awalnya hanya mengambil lokasi di Mesjid Agung Baitul Makmur Curup, mengingat bahwa mesjid ini adalah mesjid terbesar di kota Curup dan juga sebagai mesjid yang langsung dikelola oleh pemerintah Daerah. Mesjid ini juga sebagai pusat kajian dan acara-acara yang diadakan oleh pemerintah di setiap saat, termasuk bulan Ramadhan. Maka peneliti mencoba untuk melakukan penelitian di mesjid ini selama bulan Ramadhan, dengan mendengar hadis-hadis yang disampaikan oleh para mubaligh dalam bertaushiyah. (Tetapi berdasarkan masukan dari reviewer di saat seminar proposal, ada baiknya dilakukan beberapa mesjid dua atau tiga. Berdasarkan usulan ini peneliti mengambil mesjid Aljihad Curup yang terletak di Pasar tengah di pusat Kota yang sangat ramai dikunjungi jamaah setiap saat. Kemudian sebagai bandingan informasi peneliti juga mengambil salah satu mesjid yang agak kecil yaitu mesjidNurul Huda Air Sengak. Bagaimana pula sesungguhnya hadis-hadis yang disampaikan mubaligh di mesjid ini).

Di Mesjid Agung Peneliti mengambil sampel 10 malam, dengan inventaris hadishadis beserta mubalighnya sebagai berikut.

1. Pada tanggal 3 Juni dengan Ustadz $\mathbf{N}$ dengan judul ceramah "Keluarga sebagai pendidik utama akhlak anak". Salah satu hadis yang beliau sampaikan dalam

Beirut: Daar al-Fikr, 1975, cet. Ke-III, hlm. 302. Hadis Dha'if adalah hadis yang tidak memenuhi persyaratan hadis shabih dan hasan, Lihat Ibid., hlm. 337. Hadis Maudhu' adalah Kebohongan yang dibuat dengan sengaja atas Nabi SAW., Lihat Zuhdi Rifa"i Mengenal Ilmu Hadis, Al-Ghuraba, 2008, hlm. 222 
mendukung ceramahnya adalah tentang setiap manusia dilahirkan dalam keadaan suci atau fitrah. Bunyi hadis tersebut adalah:

Hadis Shohih Bukhari no. 1296

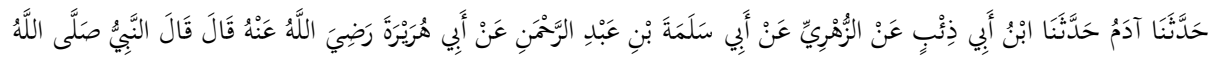

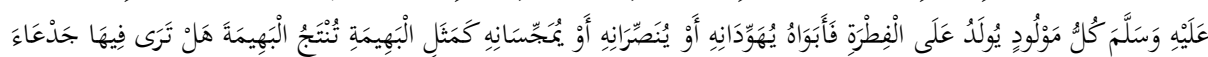

Telah menceritakan kepada kami Adam telah menceritakan kepada kami Ibnu Abu Dra'bi dari Az Zubriy dari Abu Salamah bin 'Abdurrabman dari Abu Hurairah radliallahu 'anhu berkata; Nabi Shallallabu'alaibiwasallam bersabda: "Setiap anak dilabirkan dalam keadaan fithrah. Kemudian kedua orang tuanyalah yang akan menjadikan anak itu menjadi Yabudi, Nashrani atau Majusi sebagaimana binatang ternak yang melabirkan binatang ternak dengan sempurna. Apakah kalian melibat ada cacat padanya?" (Lihat juga Musnad Ahmad no.14277 dan Sunan Tirmidzi no.2064)

Penulis melihat hadis ini termuat di berbagai kitab hadis, di antaranya kitab Shahih Bukhariy, Kitab Sunan Turmudziy dan kitab musnad Ahmad bin Hanbal, redaksi yang sedikkit berbeda juga terdapat dalam kitab Muslim dan Abu daud. Berdasarkan informasi di atas, sebagai langkah awal hadis ini bisa dijadikan hujjah dan dinyatakan dapat diterima, karena terdapat dalam beberapa kitab hadis yang populer. Selanjutnya jika dilihat dari matan hadisnyapun tidak ada bertentangan dengan aayat Alquran, hadis yang lebih kuat, fakta sejarah dan sabda kenabian. Maka hadis yang disampaikan oleh mubaligh ini dapat diterima dan diamalkan.

2. Pada tanggal 5 Juni dengan Mubaligh M.S dengan judul ceramah "Golongan Hamba Allah yang dirindukan Syurga"

Sebagaimana hadist Rasulullah SAW, ada 4 golongan manusia yang dirindukan syurga;

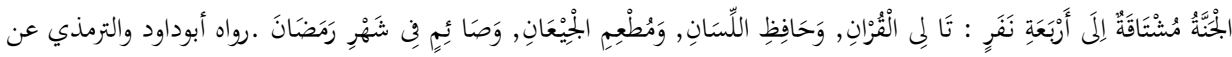

$$
\begin{aligned}
& \text { ابن عباس }
\end{aligned}
$$

"Surga rindu kepada empat golongan yaitu pembaca al-Qur'an, penjaga lisan, pemberi makan orang yang kelaparan dan orang yang berpuasa di bulan Ramadhan” (al khubawi).

Keterangan: a) Hadis ini diriwayatkan oleh al Khubawi. Dinukil dari kitab al Raunaq al Majalis (kitab hikayat, bukan kitab hadis); b) Kualitas hadisnya adalah palsu. Karena tidak ada hadis yang meriwayatkan bahwa surga merindu atau tidak. ${ }^{3}$

Maka hadis ini tidak dapat dijadikan hujjah atau dalil dalam kehidupan, karena masih banyak hadis shabih dan hasan yang lain ynang bisa dijadikan dalil.

3. Pada tanggal 8 Juni dengan Mubaligh ES dengan judul "Ciri-ciri orang yang bertaqwa"

Taushiyah malam ini mubaligh tidak menggunakan dalil hadis Rasulullah dalam menguatkan isi taushiyahnya.

${ }^{3}$ Musthafa Ali Yaqub, Hadis-Hadis Palsu Seputar Ramadhan, dan Ahmad Luthfi Fathullah, Hadis-Hadis Lemah Palsu Dalam Kitab Durratun Nasibin. 
4. Pada tanggal 10 Juni dengan Mubaligh YD dengan judul ceramah "Keutamaan membaca Alquran"

Hadis Abu Hurairah tentang siapakah yang berhak dipergauli dengan baik.

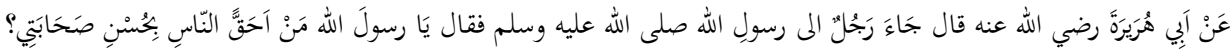

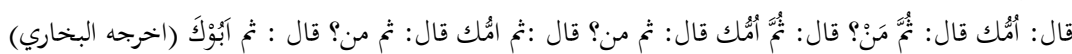

Dari Abu Hurairah r.a. ia berkata: "Suatu saat ada seorang laki-laki datang kepada Rasulullab SAW, lalu bertanya: "Wahai Rasulullah, siapakah yang berhak aku pergauli dengan baike?" Rasulullah menjawab: "Ibumu!", lalu siapa? Rasulullab menjawab: "Ibumu!”, lalu siapa? Rasulullah menjawab: "Tbumu!”. Sekali lagi orang itu bertanya: kemudian siapa? Rasulullah menjawab: “Bapakmu!”(H.R.Bukhari).

Dari shahabat Abu Umamah Al-Babili radbiallahu 'anhu: Saya mendengar Rasulullah shalallabu 'alaibi wasallam bersabda :

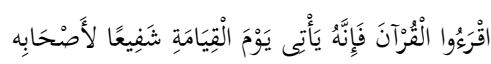

"Bacalah oleh kalian Al-Qur'an. Karena ia (Al-Qur'an) akan datang pada Hari Kiamat kelak sebagai pemberi syafa'at bagi orang-orang yang rajin membacanya." [HR. Muslim 804]

Dari shahabat Utsman bin 'Affan radbiallabu 'anhu berkata, bahwa Rasulullah shalallahu 'alaibi wasallam bersabda :

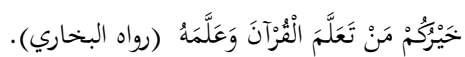

"Sebaik-baik kalian adalah yang mempelajari Al-Qur'an dan mengajarkannya." [Al-Bukhari 5027]

Ibnu Mas'ud radhiallahu 'anhu meriwayatkan bahwa Nabi shallallahu 'alaihi wasallam bersabda,

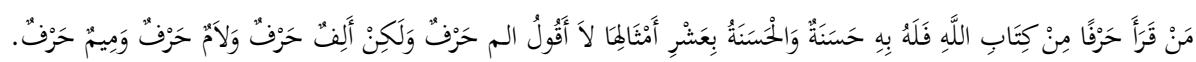

"Barangsiapa yang membaca satu buruf dari kitab Allah, maka baginya satu kebaikan, dan satu kebaikan itu dibalas sepuluh kali lipat. Saya tidak mengatakan 'Alif Lam Mim' satu buruf, tetapi 'Alif' satu huruf, 'Lam' satu huruf, 'Mim' satu buruf.” (HR. At-Tirmidzi).

Keempat hadis yang disampaikan ustadz di atas adalah hadis-hadis yang dapat diterima dan diamalkan dalam kehidupan, karena semuanya terdapat dalam kitabhadis yang kuat, dan tidak ada ulama yang mengatakan sebagai hadis dhaif dan maudhu'. Sedangkan matan-matan hadis tersebut juga tidak ada yang bertentangan dengan nash Alquran, hadis yang lebih kuat, amalan sahabat dan sabda kenabian, serta hadis tersebut tidak menyalahi fakta sejarah. Seperti tolak ukur yang disampaikan oleh Salahuddin al-Adlabiy, salah seorang ulama hadis yang berupaya menyimpulkan dan merumuskan tanda-tanda ke-shabih-an matan dari berbagai tolak ukur yang dikedepankan pada ulama, dan sekaligus dijadikan kerangka teori pada 
tulisan ini. Tolak ukur dimaksud adalah:4 1) Tidak bertentangan dengan petunjuk AlQuran al-Karim; 2) Tidak bertentangan dengan hadis Rasulullah yang lebih kuat; 3) Tidak bertentangan dengan akal sehat, indera dan sejarah; 4) Susunan pernyataannya menunjukkan ciri-ciri sabda Rasulullah.

Peneliti melihat hadis-hadis dia atas dapat diamalkan dalam kehidupan.

5. Pada tanggal 11 Juni dengan mubaligh BD dengan judul ceramah "Alquran sebagai penyembuh"

Dalam ceramahnya beliau menyampaikan bahwa banyak ayat Alquran yang digunakan.

6. Pada tanggal 12 Juni ustadz TA dengan judul ceramah "Kiat menjaga nilai-nilai Ramadhan"

Malam ini mubaligh yang menyampaikan ceramah juga tidak menguatkan dengan hadis-hadis Rasulullah, tetapi menguatkan dengan ayat-ayat Alquran tentang kiat menjaga Ramadhan.

7. Pada tanggal 13 Juni dengan ustadz $\mathbf{A H}$ dengan tema ceramah "Akhlak muslim dalam bermasyarakat"

Dari Abu Hurairah, ia berkata,

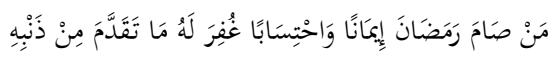

"Barangsiapa berpuasa Ramadhan atas dasar iman dan mengharap pahala dari Allah, maka dosanya yang telah lalu akan diampuni.” (HR. Bukbari no. 38 dan Muslim no. 760).

Hadis yang disampaikan mubaligh ini terdapat dalam kitab Shahih Bukhariy dan Muslim atau disebut juga dengan mutafaqqun 'alaibi. Hadis ini mempunyai sanad yang shabih, sehingga boleh dilanjutkan kepada penelitian matan. Kalau diloihat dari redaksi matanpun hadis ini juga tidak satupun menyalahi tolak ukur sebuah matan yang shahih yang telah ditetapkan oleh Salahudin al-Adlabi.

Hadis ini jika dipahami secara tekstual, siapa yang berpuasa atas dasar iman yaitu berpuasa karena meyakini akan kewajiban puasa. Sedangkan yang dimaksud ihtisab adalah mengharap pahala dari Allah Ta'ala. ${ }^{5}$

Al Khattabi berkata, "Yang dimaksud ibtisab adalah terkait niat yaitu berpuasa dengan niat untuk mengharap balasan baik dari Allah. Jika seseorang berniat demikian, ia tidak akan merasa berat dan tidak akan merasa lama ketika menjalani puasa." "Hadis yang dikaji di atas menunjukkan bahwa orang yang berpuasa dengan benar akan didasari dengan iman dan ikhlas semata-mata hanya mengharap ridha Allah, bukan melakukannya atas dasar riya', cari pujian atau hanya sekedar mengikuti kebiasaan orang sekitar.

8. Selanjutnya 14 Juni dengan mubaligh B dengan judul taushiyah "I'tikaf"

Hadis yang disampaikan oleh ustadz dalam taushiyahnya malam tersebut adalah tentang i'tikaf. Bunyi hadis tersebut adalah:

${ }^{4}$ Salahuddin bin Ahmad al-Adlabiy, Manhaj Naqd al-Matn, Daar al-Afaq al-Jadidah: Beirut, 1403 H, /1983 M., h. 238

${ }^{5}$ Lihat muhammad Fuad Abdul Baqi, Fathul Bariy, jilid 4 hlm.115

${ }^{6}$ Lihat muhammad Fuad Abdul Baqi, Fathul Bariy, jilid 4 hlm.115 


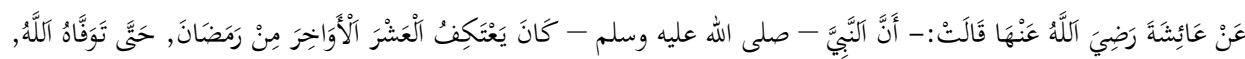

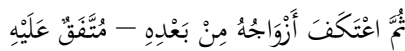

Dari 'Aisyah radhiyallahu 'anha, ia berkata bahwasanya Nabi shallallahu 'alaihi wa sallam biasa beri'tikaf di sepuluh hari terakbir dari bulan Ramadhan hingga beliau diwafatkan oleh Allah. Lalu istri-istri belian beri'tikaf setelah beliau wafat. Muttafaqun 'alaih. (HR. Bukhari no. 2026 dan Muslim no. 1172).

Hadis yang disampaikan ini juga terdapat dalam kitab Shahih Bukhariy dan Muslim, maka menurut hemat peneliti sebagai standar penilaian jika terdapat dalam kitab hadis yang sembilan sebagai langkah awal sudah bisa dijadikan hujjab selama tidak ada yang janggal dan sakit di sana. Selanjutnya jika dilihat dari matannya, hadis inipun tidak ada yang menyalahi ayat Alquran, hadis yang lebih kuat, fakta sejarah dan indera yang sehat serta tidak menyalahi sabda kenabian.

9. Tanggal 19 Juni dengan ustadz INH dengan judul ceramah "Menjaga shilaturrahmi sepanjang masa"

Hadis yang disampaikan oleh mubaligh dalam bertaushiyah adalah sebagai berikut"Rasûlullâh Shallallahu 'alaihi wa sallam bersabda:

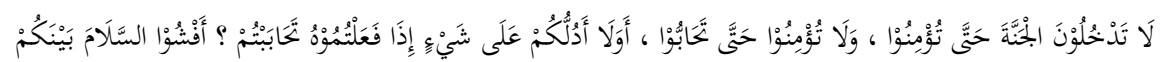

Tidak akan masuk surga sampai kalian beriman, dan kalian tidak beriman sampai kalian saling mencintai. Maukah kalian aku tunjukkan sesuatu yang jika kalian kerjakan maka kalian akan saling mencintai? Sebarkanlah salam di antara kalian.

Al-Imaam Al-Bukhaariy rabimabullah berkata:

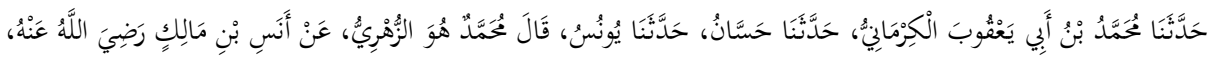

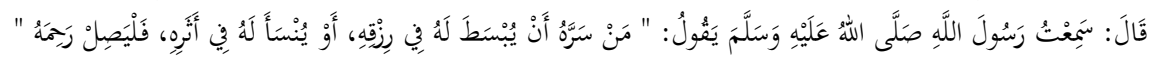

Telah menceritakan kepada kami Muhammad bin Abi Ya'quub Al-Kirmaaniy[1]: Telah menceritakan kepada kami Hassaan [2]: Telah menceritakan kepada kami Yuunus[3]: Telah berkata Muhammad - ia adalah Az-Zubriy [4] - dari Anas bin Maalik radliyallaabu 'anhu, ia berkata: Aku mendengar Rasulullah shallallaahu 'alaibi wa sallam bersabda: "Barangsiapa yang suka diluaskan rizkinya dan ditanggubkan kematiannya, hendaklah ia menyambung silaturahim" [Shabiih Al-Bukhaariy no. 2067].

Hadis yang disampaikn oleh ustadz tersebut juga terdapat dalam kitab Shahih Bukhariy sehingga berdasarkan kriteria penelitian penulis bisa dijadikan hujjah. Selanjutnya jika dilihat dari segi matan hadis, hadis inipun tidak bertentangan dengan ayat Alquran, hadis-hadis yang lebih kuat, panca indera dan fakta sejarah serta menunjukkan sabda kenabian. Maka menurut peneliti hadis ini adalah maqbul atau atau diterima dan diamalkan.

10. Tangal 30 Mei dengan mubaligh H.AM dengan judul taushiyah "Ramadhan penuh berkah"

Dari Abu Hurairah, ia berkata, 


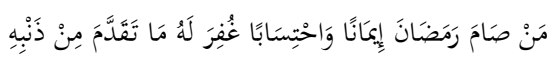

"Barangsiapa berpuasa Ramadhan atas dasar iman dan mengharap pabala dari Allah, maka dosanya yang telah lalu akan diampuni." (HR. Bukhari no. 38 dan Muslim no. 760).

Hadis pertama yang dijadikan dalil oleh ustadz yang menyampaikan taushiyah terdapat dalam kitab Shabih Bukhariy dan Shabih Muslim. Maka hadis ini bisa dilanjutkan kepada pemahaman matan. Jika dilihat dari matannya hadis ini juga tidak bertentangan dengan tolak ukuir matan shahih seperti yang diungkapkan oleh Shalahudin al-Adlabi. Maka hadis ini juga bisa dijadikan hujjah dan diamalkan dalam kehidupan. Hanya saja yang dimaksud dengan kata ibtisaaban dari matan tersebut adalah keihklasan seperti yang sudah dijelaskan sebelumnya.

Selanjutnya ustadz juga menyampaikan hadis tentang keutamaan malammalam Ramadhan. Hadis yang disebutkan beliau adalah artinya saja, yaitu seorang muslim yang melakukan shalat tarawih malam kelima sama seperti melaksanakan shalat di mesjidil Haram, Masjid Nabawi dan mesjid Aqsha.

Padabab Keistimewaan Ramadhan dari Ali bin Abi Thalib RA bahwa dia berkata: Nabi Muhammad SAW ditanya tentang keutamaan-keutamaan tarawih di bulan Ramadhan. Kemudian Beliau menyampaikan "Seorang Muslim yang melaksanakan Sholat Tarawih dari Malam Pertama hingga Malam Terakbir (Ke-29 atau 30), maka Fadhilah (Kebaikan) yg Allah SWT sediakan baginya pada tiap malam adalab" Mengingat hadisnya sangat panjang hanya akan dipaparkan terjemahannya saja, 1) Orang mukmin keluar dari dosanya pada malam pertama, seperti saat dia dilahirkan oleh ibunya; 2) Dan pada malam kedua, ia diampuni dan juga kedua orang tuanya (diampuni dosa-dosanya), jika keduanya mukmin; 3) 3. Dan pada malam ketiga, seorang malaikat berseru dibawah 'Arsy: "Mulailah beramal, karena ALLAH telah mengampuni dosamu yang telah lewat."; 4) Pada malam keempat, dia memperoleh pahala seperti pahala membaca Taurat, Injil, Zabur, dan Al-Furqan (Al-Qur'an); 5) Pada malam kelima, Allah SWT memeberikan pahala seperti pahala orang yang shalat di Masjidil Haram, Masjid Madinah (Nabawi) dan Masjidil Aqsha; 6) Pada malam keenam, Allah SWT memberikan pahala orang yang berthawaf di Baitul Makmur dan dimohonkan ampun oleh setiap batu dan cadas; 7) Pada malam ketujuh, seolah-olah ia mencapai derajat Nabi Musa AS dan kemenangan Beliau atas Fir'aun dan Haman; 8) Pada malam kedelapan, Allah SWT memberinya apa yang pernah Allah SWT berikan kepada Nabi Ibrahin as; 9) Pada malam kesembilan, seolah-olah ia beribadat kepada Allah SWT sebagaimana ibadatnya Nabi Muhammad SAW; 10) Pada Malam kesepuluh, Allah SW'T mengkaruniai dia kebaikan dunia dan akhirat; 11) Pada malam kesebelas, ia keluar dari dunia seperti saat ia dilahirkan dari perut ibunya; 12) Pada malam keduabelas, ia datang pada hari kiamat sedang wajahnya bagaikan bulan di malam purnama; 13) Pada malam ketigabelas, ia datang pada hari kiamat dalam keadaan aman dari segala keburukan; 14) Pada malam keempat belas, para malaikat datang seraya memberi kesaksian untuknya, bahwa ia telah melakukan shalat tarawih, maka Allah SWT membebaskannya dari Hisab pada hari kiamat; 15) Pada malam kelima belas, ia didoakan oleh para malaikat dan para penanggung (pemikul) Arsy dan Kursi; 16) 
Pada malam keenam belas, Allah SWT tetapkan baginya kebebasan untuk selamat dari neraka dan kebebasan masuk ke dalam Surga; 17) Pada malam ketujuh belas, Allah SWT berikan padanya pahala seperti pahala para Nabi; 18) Pada malam kedelapan belas, seorang malaikat berseru, "Hai hamba Allah SWT, sesungguhnya Allah SWT ridha kepadamu dan kepada ibu bapakmu."; 19) Pada malam kesembilan belas, Allah SWT mengangkat derajat-derajatnya dalam Surga Firdaus; 20) Pada malam kedua puluh, Allah SWT memberikannya pahala para Syuhada (orang-orang yang mati syahid) dan shalihin (orang-orang yang saleh); 21) Pada malam kedua puluh satu, Allah SW'T membangunkan untuknya sebuah gedung dari cahaya; 22) Pada malam kedua puluh dua, ia datang pada hari kiamat dalam keadaan aman dari setiap kesedihan dan kesusahan; 23) Pada malam kedua puluh tiga, Allah SWT membangunkan untuknya sebuah kota di dalam surga; 24) Pada malam kedua puluh empat, ia memperoleh 24 (duapuluh empat) doa yang dikabulkan; 25) Pada malam kedua puluh lima, Allah SWT membebaskannya dari azab kubur; 26) Pada malam keduapuluh enam, Allah SWT mengangkat pahalanya selama empat puluh tahun; 27) Pada malam keduapuluh tujuh, ia dapat melewati Shiroth pada hari kiamat, bagaikan kilat yang menyambar; 28) Pada malam keduapuluh delapan, Allah SWT mengangkat baginya 1000 (seribu) derajat dalam surga; 29) Pada malam kedua puluh sembilan, Allah SWT memberinya pahala 1000 (seribu) haji yang diterima; 30) Dan pada malam ketiga puluh, ALLAH SW'T berfirman: "Hai hamba-Ku, makanlah buah-buahan surga, mandilah dari air Salsabil dan minumlah dari telaga Kautsar. Akulah Tuhanmu, dan engkau hamba-Ku."

Hadis ini jika dilihat dari sumbernya tidak ditemukan, setelah dilihat ke sumber lain ternyata hadis ini adalah palsu. Di antara pendapat yang menyatakan hadis ini palsu dikarenakan terlihat adanya indikasi tentang kepalsuan sebuah hadis.Perlu diketahui bahwasanya hadis yang munkar dan palsu membuat hati penuntut ilmu menjadi geli dan mengingkarinya. Rabi' bin Hutsaim rahimahullah mengatakan, "Sesungguhnya hadis itu memiliki cahaya seperti cayaha di siang hari, sehingga engkau dapat melihatnya. Dan memiliki kegelapan seperti gelapnya malam, sehingga engkau mengingkarinya."7

Berikut ini beberapa indikasi atas palsunya hadis tersebut: a) Pahala yang terlalu besar untuk amalan yang sederhana. Banyak keutamaan-keutamaan yang terdapat dalam hadis di atas termasuk dalam kejanggalan jenis ini, misalkan pada lafadz "Allah memberinya pahala seribu haji yang diterima."; b) Bahkan, yang lebih parah adalah seseorang bisa mendapatkan pahala sebanding dengan pahala para Nabi (keutamaan shalat tarawih malam ke-17). Hal tersebut mustahil terjadi, karena sebanyak apapun amalan ibadah manusia biasa, tentu dia tidak akan mampu menyamai pahala Nabi. Nubuwah merupakan pilihan dari Allah semata. Allah Ta'ala berfirman (yang artinya), "Allah memilih_utusan-utusan-(Nya) dari malaikat dan dari manusia. Sesungguhnya Allah Maha Mendengar lagi Maha Melihat." (QS. Al Hajj [22] : 75) ${ }^{8}$; c) Tidak terdapat dalam kitab-kitab hadis yang mu'tamad. Hadis tentang 30 keutamaan shalat tarawih di atas, tidak terdapat dalam kitab-kitab hadis

${ }^{7}$ Lihat Ibnu al-Jauziy, Almaudhun'at nomor 605

${ }^{8}$ Lihat Ibnu Qayyim al-Jauziyyah, Manaarul Muniif, hlm. 55-105 
yang mu'tamad. DR. Lutfi Fathullah mengatakan, "Jika seseorang mencari hadis tersebut di kitab-kitab referensi hadis, niscaya tidak akan menemukannya." Hal tersebut mengindikasikan bahwa hadis tersebut adalah hadis palsu. ${ }^{9}$

\section{Masjid Al-Jihad Curup}

1. Tanggal 5 Juni dengan mubaligh $\mathbf{K H}$

Tidak ada dalil hadis yang beliau sampaikan, hanya ayat-ayat Al-qur'an yang dijadikan dalil dalam memberikan taushiyahnya.

2. Tanggal 7 Juni dengan ustadz SG dengan judul taushiyah "Tujuan otonomi daerah"

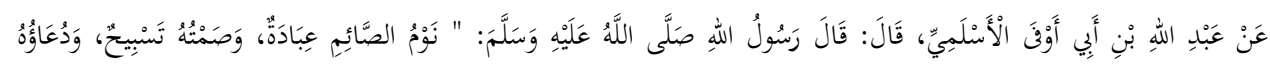

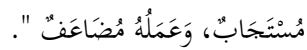

"Abdullah bin Abi Aufa Al Aslami radhiyallahu 'anbu berkata: "Rasulullah shallallabu 'alaibi wasallam bersabda: "Tidurnya orang puasa adalah ibadah, diamnya adalab tasbih, doanya dikabulkan dan amalannya dilipatkean (pabalanya-pent)."

Al Baihaqi rahimahullah berkata :

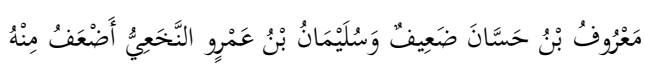

"Ma'ruf bin Hassan (salah satu perawi hadis ini) adalah perawi yang lemah dan Sulaiman bin 'Amr An Nakh'i lebih lemah darinya." Lihat kitab Syu'ab Al Iman, $5 / 423$ (Syamela).

Al Munawi rahimahullah berkata:

$$
\text { وأحمد : مضطرب الحافظ العراقي : فيه سليمان النخعي أحد الكذابين اه وأقول : فيه أيضا عبد الملك بن عمير أورده الذهبي في الضعفاء ، وقال }
$$

"Al Hafizh Al Traqi berkata: 'Di dalam sanadnya terdapat Sulaiman An Nakha'i, ia adalah salah satu tukang dusta, dan aku (Al Munawi) berkata: "Di dalam sanadnya terdapat Abdul Malik bin Umair disebutkan oleh Adz Drahabi di dalam kitab Adh Dhu'afa (kitab yang menyebutkan para perawi lemab), dan Ahmad (bin Hambal) berkata: "I seorang yang guncang hadisnya", Ibnu Ma'in berkata: "Seorang perawi yang tercampur hapalannya", Abu Hatim berkata: "Bukan seorang yang hafizh (menjaga hadis)." Lihat kitab Faidh Al Qadhir, 6/378 (Syamela).

Syaikh Muhammad Nashiruddin Al Albani rahimahullah berkata: dhaif

3. Selanjutnya ustadz MK dengan judul taushiyah "Amal yang disukai Allah"

Hadis Abdullah bin Mas'ud tentang amal yang paling disukai Allah SWT.

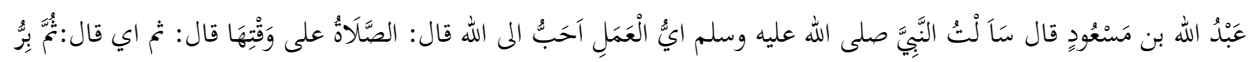

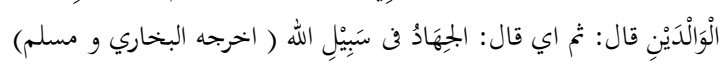

${ }^{9}$ Luthfi Fathullah,Hadis-hadis Lemah dan Palsu dalam Kitab Durrotun Nashibiin, 
"dari Abdullah bin Mas'ud r.a. ia berkata: "Saya bertanya kepada Nabi saw: amal apakah yang paling disukai oleh Allah Ta'ala?" beliau menjawab: " shalat pada waktunya. " saya bertanya lagi: "kemudian apa?" beliau menjawab: "berbuat baik kepada kedua orang tua. " saya bertanya lagi: "Kemudian apa?" beliau menjawab: "berjihad(berjuang) di jalan Allah." (H.R. Bukhari dan Muslim).

\section{Di antara Keutamaan Shalat Tarawih dari Hadis yang Shahih}

Rasulullah shallallabu 'alaibi wa sallam bersabda,

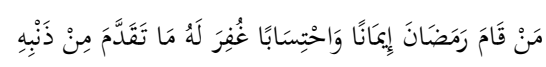

"Barang siapa melakukan qiyam Ramadhan karena iman dan mencari pahala, maka dosadosanya yang telab lalu akan diampuni." (HR. Bukhari no. 37 dan Muslim no. 759).

Yang dimaksud qiyam Ramadhan adalah shalat tarawih sebagaimana yang dituturkan oleh Imam Nawawi (Al Minhaj Syarh Shabih Muslim, 6:39)

Selain itu, beliau beliau juga pernah mengumpulkan keluarga dan para shahabatnya. Lalu beliau bersabda,

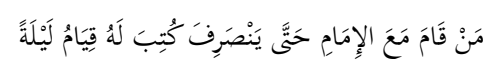

"Siapa yang shalat bersama imam sampai ia selesai, maka ditulis untuknya pabala qiyam satu malam penub" (HR. An-Nasai dan selainnya, dishahihkan oleh Syaikh al-Albani dalam al-Irwa' no. 447)

Semoga Allah selalu melimpahkan karunai-Nya kepada kita semua, dan menjaga lisan-lisan kita dari perkataan dusta, apalagi berdusta atas nama Rasulullah shallallabu 'alaibi wa sallam.

4. Selanjutnya tanggal 15 Juni ustadz $\mathbf{H}$. TS dengan judul taushiyah "Islam agama yang disiplin"

Ramadhan itu dibagi 3, 10 pertama adalah rahmah, 10 kedua adalah maghfirah dan 10 ketiga adalah dijauhkan dari api neraka.

Diriwayatkan oleh Al Mahamili dalam Amaliyyah (293), Ibnu 'Adi dalam Al Kamil Fid Dhu'afa (6/512)

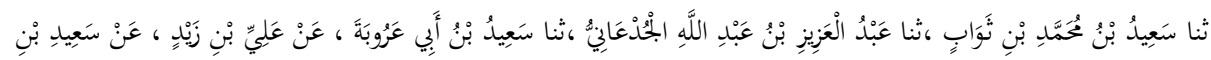

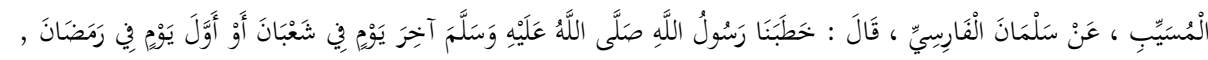

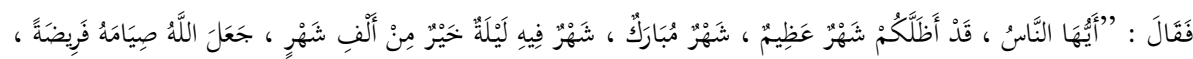

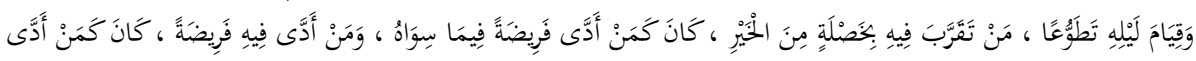

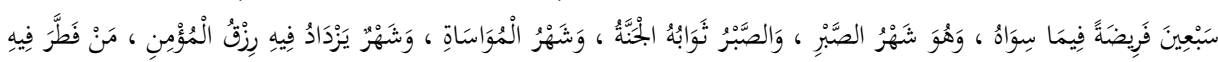

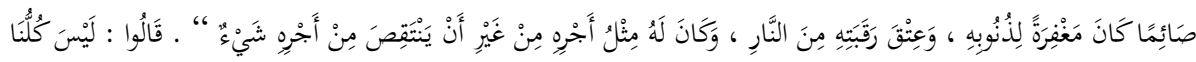

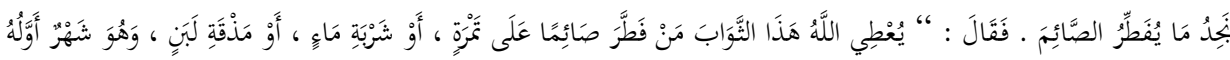

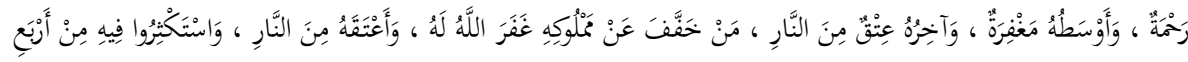

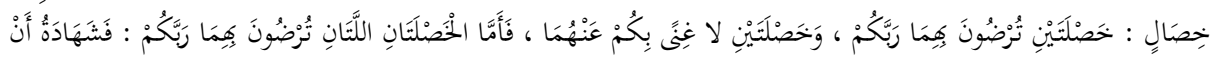




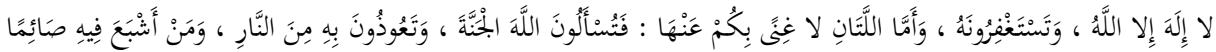

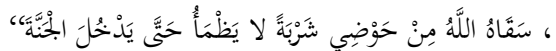

Sa'id bin Muhammad bin Tsawab menuturkan kepadaku, Abdul Aziz bin Abdillah Al Jud'ani menuturkan kepadaku, Sa'id bin Abi 'Arubah menuturkan kepadaku, dari Ali bin Zaid, dari Sa'id bin Musayyib, dari Salman Al Farisi, ia berkata: Rasulullah Shallallahu'alaibi Wasallam berkhutbah kepada kami di akhir hari bulan Sya'ban atau di awal hari bulan Ramadhan, beliau bersabda: "Wabai manusia, bulan yang agung telah mendatangi kalian. Di dalamnya terdapat satu malam yang lebih baik dari 1000 bulan. Allah menjadikan puasa pada siang harinya sebagai sebuah kewajiban, dan menghidupkan malamnya sebagai ibadah tathawnu' (sunnah). Barangsiapa pada bulan itu mendekatkan diri (kepada Allah) dengan satu kebaikan, ia seolah-olah mengerjakan satu ibadah wajib pada bulan yang lain. Barangsiapa mengerjakan satu perbuatan wajib, ia seolah-olah mengerjakan 70 kebaikan di bulan yang lain. Ramadhan adalah bulan kesabaran, sedangkan kesabaran itu balasannya adalah surga. Ia (juga) bulan tolong-menolong. Di dalamnya rezki seorang mukmin ditambah. Barangsiapa pada bulan Ramadhan memberikan bidangan berbuka kepada seorang yang berpuasa, dosa-dosanya akan diampuni, diselamatkan dari api neraka dan memperoleh pahala seperti orang yang berpuasa itu, tanpa mengurangi pabala orang yang berpuasa tadi sedikitpun" Kemudian para sababat berkata, "Wabai Rasulullah, tidak semua dari kita memiliki makanan untuk diberikan kepada orang yang berpuasa." Rasulullab Shallallabu'alaibi Wasallam berkata, "Allah memberikan pahala tersebut kepada orang yang memberikan bidangan berbuka berupa sebutir kurma, atau satu teguk air atau sedikit susu. Ramadhan adalah bulan yang permulaannya rahmat, pertengahannya maghfirah (ampunan) dan akbirnya pembebasan dari api neraka".

Juga diriwayatkan oleh Ibnu Khuzaimah (1887) dari Ali bin Hujr As Sa'di, dari Yusuf bin Ziyad, dari Hammam bin Yahya dari Ali bin Zaid bin Jud'an, dari Sa’id bin Musayyab dari Salman Al Farisi.

Hadis ini lemah karena terdapat perawi Ali bin Zaid bin Jud'an. Yahya bin Ma'in berkata: "ia dha'if dalam segala hal". Imam Ahmad berkata: "dhai'ful hadis". Ad Daruquthni berkata: "fihi layyin". Ali Al Madini berkata: "ia dhaif menurut kami". Adz Dzahabi berkata: "ia salah seorang buffadz, namun tidak tsabt".

Namun At Tirmidzi menyatakan: "shaduq". Tapi yang tepat adalah sebagaimana yang dikatakan Ibnu Hajar: "dhai'ful badis, hadisnya tidak bisa dihasankan kecuali dengan mutaba'ah dan syawabid". Dan untuk Ali bin Zaid ini tidak terdapat mutaba'ah yang menguatkannya. ${ }^{10}$

Menurut hemat peneliti, hadis ini tidak bisa diamalkan karena dhaif, maka sebaiknya diambil hadis-hadis shahib lain berbicara masalah ramadhan.

${ }^{10}$ Hadis ini didhaifkan oleh para pakar hadis seperti Al 'Aini dalam 'Umdatul Qari (10/383), Al Mundziri dalam At Targbib Wat Tarbib (2/115), Al Albani dalam Takbrij Al Misykah (1906), juga didhaifkan oleh Syaikh Ali Hasan Al Halabi di Sifatu Shaumin Nabiy (110). 
5. Pada tanggal 16 Juni ustadz $\mathbf{B H}$ dengan judul ceramah "Keutamaan membaca Alquran"

Ibnu Mas'ud radhiallahu 'anhu meriwayatkan bahwa Nabi shallallahu 'alaihi wasallam bersabda,

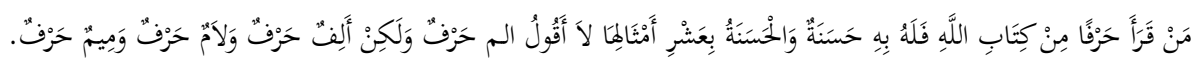

"Barangsiapa yang membaca satu huruf dari kitab Allah, maka baginya satu kebaikan, dan satu kebaikan itu dibalas sepulub kali lipat. Saya tidak mengatakan 'Alif Lam Mim' satu buruf, tetapi 'Alif' satu buruf, 'Lam' satu huruf, 'Mim' satu huruf.” (HR. At-Tirmidzi).

Hadis yang disampaikan oleh mubaligh ini jika dilihat dari standar teori penelitian penulis sudah termasuk ke dalam kitab Imam Tirmidziy, selanjutnya jika dilihat dari matannya, hadis ini juga tidak bertentangan dengan tolak ukur yang disampaikan oleh ulama hadis, yaitu tidak bertentangan ayat Alquran, hadis yang lebih kuat, panca indera dan fakta sejarah serta matannya menunjukkan sabda kenabian, karena tidak ada kejanggalan. Maka hemat peneliti hadis ini adalah maqbul atau dapat diterima dan diamalkan.

6. Berikutnya tanggal 19 Juni dengan ustadz ALB dengan judul ceramah "Lailatul Qadar"

Sebagaimana hadist Rasulullah SAW, ada 4 golongan manusia yang dirindukan syurga;

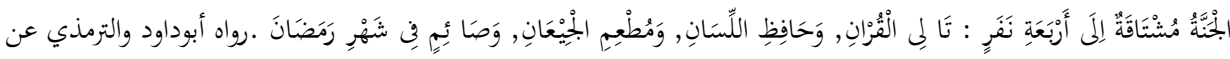

$$
\begin{aligned}
& \text { ابن عباس }
\end{aligned}
$$

Hadis ini tidak shahih. Tidak ada ketetapan dari Nabi sallallahu'alaihi wasallam. Diriwayatkan oleh Baihaqi di kitab “Syu'abul Iman", 3/1437, dari Abdullah bin Abu Aufa radhiallabu 'anbu sesungguhnya Nabi sallallahu 'alaibi wa sallam bersabda:

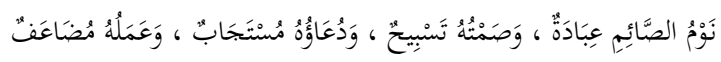

"Tidurnya orang puasa adalah ibadah, diamnya adalah tasbih, doanya terkabulkan dan amalannya dilipat gandakan”.

Sanadnya dilemahkan oleh Baihaqi, dia berkata: Ma'ruf bin Hasan (salah seorang perawi hadis ini) lemah, dan Sulaiman bin Amr An-Nakha'i lebih lemah dari beliau. Al-Iraqi berkomentar dalam Takhrij Ibya' Ulumuddin, 1/310: Sulaiman AnNakha'i adalah salah seorang pendusta. Dilemahkan juga Al-Manawi di kitab Faidhul Qadir, 9293. Al-Albany mencantumkannya dalam kitab Silsilah Al-Ahadis Ad-Dhaifah, no. 4696, dia berkata: (Hadis ini) lemah. 


\section{Tentang Berandai-Andai Ramadhan Sepanjang Tahun}

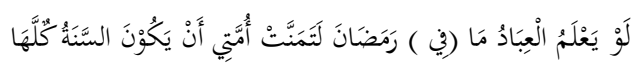

"Sekiranya manusia mengetahui apa yang ada pada buan Ramadhân, niscaya semua umatku berharap agar Ramadhân itu sepanjang tabun".

Maudhu'. Ini diriwayatkan oleh Ibnu Khuzaimah rahimahullah, no. 1886 lewat jalur periwayatan Jarîr bin Ayyûb al Bajali, dari asy-Sya'bi dari Nâfi' bin Burdah, dari Abu Mas'ud al-Ghifari- ia mengatakan, "Suatu hari, aku mendengar Rasûlullâh Shallallahu 'alaihi wa sallam pernah bersabda , "(lalu beliau menyebutkan hadis diatas).

Imam Ibnul Jauzi rahimahullah membawakan hadis di atas dalam kitab beliau rahimahullah al-Maudhû'ât, 2/189 lewat jalur periwayatan Jarîr bin Ayyûb al Bajali dari Sya'bi dari Nâfi' bin Burdah dan Abdullah bin Mas'ud Radhiyallahu 'anhu. kemudian beliau rahimahullah mengatakan, "Hadis ini maudhû' (palsu) dipalsukan atas nama Rasûlullâh Shallallahu 'alaihi wa sallam. Orang yang tertuduh telah memalsukan hadis ini adalah Jarîr bin Ayyûb.

Yahya rahimahullah mengatakan, 'Orang-orang ini tidak ada apa-apanya (laisa bi syai-in).'

Fadhl bin Dukain rahimahullah mengatakan, 'Dia termasuk orang yang biasa memalsukan hadis.'

An-Nasa'i dan Daru Quthni rahimahullah mengatakan, 'Matrûk (orang yang hadisnya tidak dianggap)."'11

Hemat peneliti hadis-hadis yang disampaikan ini adalah lemah dan palsu. Sejogyanya seorang mubaligh sebelum menyampaikan taushiyahnya harus melihat dulu refensi hadis-hadis Rasulullah apakah hadis tersebut bisa diterima (shabih dan Hasan) atau ditolak (dhaif dan mandhu').

7. Tanggal 20 Juni dengan mubaligh $\mathbf{S H}$ dengan judul taushiyah "Amar makruf nahi munkar"

Dalam sebuah hadis Rasulullah mengatakan:

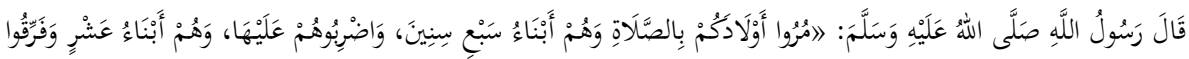

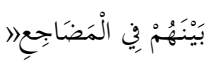

"Surublah anak-anakmu melakukan shalat di waktu dia berumur tujub tahun, dan pukullah mereka kalau sudah berumur sepulub tahun dan pisabkanlah tempat tidur di antara mereka (maksudnya antara anak laki-laki dan perempuan)". (HR. Abu Daud)

\footnotetext{
${ }^{11}$ Imam Syaukani rahimahullah dalam kitab al-Fawâ-idul Majmû'ah Fil Ahâdîtsil Maudhû'ah, no. 254 mengomentari hadis diatas, "Hadis ini diriwayatkan oleh Abu Ya'la rahimahullah lewat jalur Abdullah bin Mas'ûd Radhiyallahu 'anhu secara marfuu. Hadis ini
} 
Hadis ini juga berkategori maqbul dan bisa diamalkan karena terdapat dalam kitab hadis yang sembilan, di antaranya kitab Abu Daud. Sedangkan matan hadis inipun berkualitas shahih.

8. 21 Juni dengan ustadz MAL dengan judul Ceramah "Fakir mendekatkan pada kekafiran"

Dari Anas bin Malik Radhiallabu'anhu bahwa Rasulullah bersabda:

كادَ الفَقْرُ أنْ يَكُوْنَ كُفْرًا

\section{"Hampir-hampir kefakiran (kemiskinan) itu menjadi kekafiran"}

Hadis ini dikeluarkan oleh Imam al-Baihaqi dalam kitab "Syu'abul Iman" (no. 6612), Abu Nu'aim Al-Ashbahani dalam "Hilyatul auliyaa"' (3/53 dan 109), AlQudha-'i dalam "Musnadusy Syihab" (no. 586), Al-'Uqaili dalam "Adh-Dhu'afaa" (no. 1979) dan Ibnu 'Adi dalam "Al-Kamil' (7/236), semuanya dari berbagai jalur, dari Yazid bin Aban ar-Raqa-syi, dari Anas bin Malik Radhiallahu'anhu, dari Rasulullah Shallallahu'alaibi Wasallam. ${ }^{12}$

Hadis ini adalah hadis yang lemah, karena dalam sanadnya ada Yazid bin Aban Ar-Raqasyi, dia dinyatakan lemah oleh para ulama Ahli hadis, seperti Imam Ahmad, Yahya bin Ma'in, an-Nasa-i, ad-Daraquthni, adz-Dzahabi dan Ibnu Hajar al-'Asqalani.

Hadis ini dihukumi lemah, karena lemahnya perawi di atas, oleh Imam Ibnul Jauzi, al-'Iraqi dan as-Sakhawi.

Adapun Syaikh al-Albani, beliau menghukumi hadis ini sebagai hadis palsu, karena dalam sanad yang beliau nukil ada rawi yang suka memalsukan hadis. Di tempat lain, beliau menghukumi hadis ini sebagai hadis yang lemah.

Hadis ini juga diriwayatkan dari jalur lain, dari Anas bin Malik Radbiallabu'anbu, dari Rasulullah Shallallabu'alaibi Wasallam, dengan redaksi yang senada. ${ }^{13}$ Dikeluarkan oleh Imam ath-Thabrani dalam "al-Mu'jamul ausath" (4/225, no. 4044).

Tapi hadis ini juga lemah, karena dalam sanadnya ada rawi yang bernama 'Amr bin 'Utsman al-Kilabi, Imam adz-Dzahabi dan Ibnu Hajar menyatakannya sebagai rawi yang lemah, bahkan Imam al-Haitsami mengatakan bahwa dia ditinggalkan (riwayat hadisnya karena kelemahannya yang fatal). Hadis ini dinyatakan lemah oleh Imam al-'Iraqi dan al-Haitsami.

Hadis ini juga diriwayatkan dari Shahabat lain, yaitu 'Umar bin alKhattab Radhiallabu'anhu, dari Rasulullah Shallallabu'alaibi Wasallam.

Hadis ini juga lemah, dalam sanadnya ada rawi yang bernama Ma'mar bin Zaidah, dia rawi yang lemah dan riwayat hadisnya tidak didukung dengan riwayat

12 Maudhû (palsu). Kerusakannya ada pada Jarîr bin Ayyûb dan susunan lafazhnya merupakan susunan yang bisa dinilai oleh akal bahwa itu adalah hadis palsu.

${ }^{13}$ Dikeluarkan oleh Imam ath-Thabrani dalam "ad-Du'a”" (hal. 319-320, no. 1048)n dan al-'Uqaili dalam "adh-Dhu'afaa”" (no. 1978). 
54 |Jurnal Dakwah dan Komunikasi, Vol. 3, No. 1, 2018

lain, sebagaimana yang dinyatakan oleh Imam al-'Uqaili dan dengan sebab inilah beliau menghukumi hadis ini sebagai hadis yang lemah.

Hadis ini juga diriwayatkan dari Shahabat lain, yaitu 'Ali bin Abi Thalib Radbiallabu'anbu dan Ibnu 'Abbas Radbiallabu'anbum, tapi kedua hadis ini sangat lemah dan palsu.

Kesimpulannya, hadis ini adalah hadis yang lemah dari semua jalur periwayatannya, bahkan sebagiannya sangat lemah dan palsu, sebagaimana penjelasan di atas. Maka hadis ini menurut hemat peneliti tidak bisa diamalkan.

9. Selanjutnya tanggal 22 Juni oleh ustadz BS dengan judul taushiyah "Mempertahankan semangat Ramadhan"

Tidak ada hadis yang disampaikan, hanya ayat-ayat Alquran tentang mempertahankan semangat ramadhan.

10. Kemudian tanggal 23 Juni ustadz MQ dengan judul taushiyyah "Cara merayakan Idul Fitri”

Dalam taushiyah ini ustadz juga tidak menyampaikan hadis-hadis Rasulullah hanya Alquran saja.

\section{Mesjid Nurul Huda Curup}

1. Pada malam 17 Juni dengan Ustadz $\mathbf{Y H}$

Dari 'Ubadah bin Shomit radhiyallabu 'anbu, Nabi shallallabu 'alaibi wa sallam bersabda,

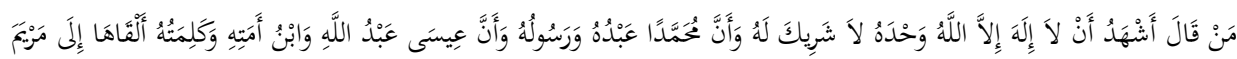

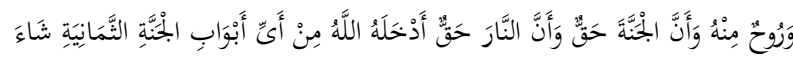

"Barangsiapa mengucapkan 'saya bersaksi bahwa tidak ada sesembahan yang berhak disembah dengan benar kecuali Allah semata, tidak ada sekutu bagi-Nya, Muhammad adalah hambaNya dan utusan-Nya, dan (bersaksi) bahwa 'Isa adalab hamba Allah dan anak dari hambaNya, dan kalimat-Nya yang disampaikan kepada Maryam serta Rub dari-Nya, dan (bersaksi pula) bahwa surga adalah benar adanya dan neraka pun benar adanya, maka Allah pasti akan memasuk.kannya ke dalam surga dari delapan pintu surga yang mana saja yang dia kehendaki." (HR. Muslim no. 149)

2. Berikutnya pada tanggal Juni dengan ustadz SA taushiyah beliau seputar zakat, dan hanya menyampaikan dalil Alquran tidak ada dari sabda Rasulullah SAW.

3. Berikutnya taushiyyah ustadz H.TS

Nabi Muhammad shallallahu 'alaibi wa sallam bersabda,

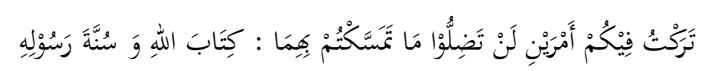

Aku telah tinggalkan pada kamu dua perkara. Kamu tidak akan sesat selama berpegang kepada keduanya, (yaitu) Kitab Allah dan Sunnah Rasul-Nya. (Hadis Shabih Lighairibi, H.R. Malik; al-Hakim, al-Baihaqi, Ibnu Nashr, Ibnu Harm. Dishabihkan oleh Syaikh Salim al-Hilali di dalam At Ta'z̧him wal Minnah fil Intisharis Sunnah, hlm. 12-13). 
Hadis yang disampaikan ini juga berstatus shahih lighairihi. Maka jika dilanjutkankepada penelitian matan, jika dilihat kepada tolak ukur matan yang shahih, hadis inipun memenuhi kriteria tersebut.

4. Berikutnya dengan ustadz SY

Sebagaimana hadist Rasulullah SAW, ada 4 golongan manusia yang dirindukan syurga;

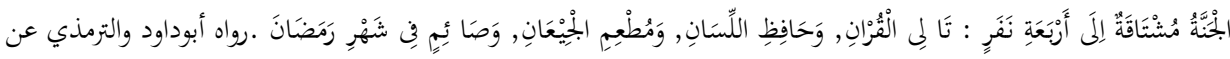

$$
\begin{aligned}
& \text { ابن عباس }
\end{aligned}
$$

Hadis ini dinilai palsu oleh para kritikus hadis sebagaimana yang telah disebutkan sebelumnya. Maka seharusnya seorang ulama harus berhati-hati dalam menyampaikan hadis, sehingga masyarakat tidak menjadi sesat.

5. Selanjutnya dengan mubaligh MD

Mubaligh yang menyampaikan taushiyah malam tersebut juga tidak menyampaikan hadis hanya Alquran

6. Berikutnya dengan ustadz $\mathbf{S}$

Taushiyah yang disampaikan ustadz tersebut juga tidak diperkuat dengan hadsis Rasulullah SAW., hanya ayat Alquran saja.

\section{Penutup}

Dari ulasan yang sudah disampaikan di atas, peneliti melihat dari hasil rekaman dan analisa hadis-hadis yang telah mereka sampaikan oleh para mubaligh selama bulan Ramadhan di mesjid Agung Baitul Makmur Curup sebagai objek utama, dan mesjid Aljihad dan mesjid Nurul sebagai objek tambahan, maka 75 persen dari hadis-tersebut berkualitas maqbul (shahih dan hasan) baik dari segi sanad maupun matan. Sehingga hadis-hadis tersebut boleh diamalkan dan dijadikan bujjah dalam masyarakat. Sedangkan 25 persen dari hadis-hadis yang disampaikan masih berkategori mardud (dhaif dan maudhu). Maka yang demikian harus ditinggalkan, karena tidak ada alasan untuk berhujjah dengan hadis dhaif yang berat, apalagi hadis palsu.

Hemat peneliti mayoritas ulama yang berdakwah di kota Curup sudah memahami pentingnya menyampaikan hadis-hadis yang berkualitas maqbul, karena ketika yang disampaikan tersebut hadis-hadis dengan kualitas mardud, maka akan berdosa dan menyesatkan masyarakat. Hal ini sesuai dengan apa yang disampaikan Rasulullah dalam sebuah hadis shahih beliau yang berbunyi

Berdusta atas nama seseorang, walaupun bukan orang yang mulia, merupakan dosa besar, lalu bagaimana jika berdusta atas nama Nabi Shallallahu alaihi wa sallam , yang perkataan dan perbuatannya merupakan syari'at? Pasti, berdusta atas nama Nabi 
Shallallahu alaihi wa sallam merupakan kemungkaran dan dosa yang besar. Imam alBukhâri meriwayatkan:

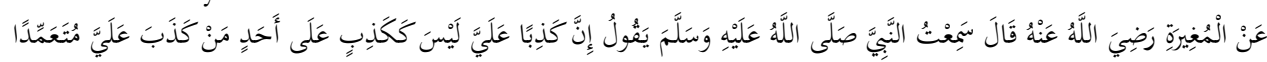

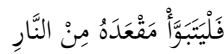

Dari al-Mughirah Radhiyallahu anhu, dia berkata, "Aku mendengar Rasullullâh Shallallahu alaihi wa sallam bersabda, "Sesungguhnya berdusta atasku tidak seperti berdusta atas orang yang lain. Barangsiapa berdusta atasku dengan sengaja, maka hendaklah dia mengambil tempat tinggalnya di neraka". ${ }^{14}$

Berdusta atas nama Nabi Shallallahu alaihi wa sallam sama dengan berdusta dalam syari'at dan dampaknya menimpa seluruh umat. Oleh karena itu, dosanya lebih besar dan hukumannya lebih berat.

Dalam hadis lain, Nabi Shallallahu alaihi wa sallam menegaskan:

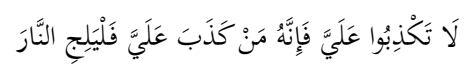

"Janganlah kamu berdusta atasku, karena sesunggubnya barangsiapa berdusta atasku, maka silabken dia masuk ke neraka."'15

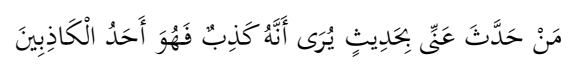

"Barangsiapa menceritakan sebuah hadis dariku, dia mengetabui bahwa hadis itu dusta, maka dia adalah salah seorang dari para pendusta." "6

Dari hasil penelitian ini, diharapkan kepada para mubaligh dalam menyampaikan taushiyah untuk memahami dengan benar hadis-hadis yang alkan disampaikan, seyogyanya tidak hanya hafal tetapi harus tau kebenaran dan kesahihan hadis tersebut. Karena jika dengan dengan sengaja berdusta atas nama rasulullah maka neraka tempatnya. Jadi kehati-hatian dan semakin memperdalam ilmu harus semakin ditingkatkan, agar masyarakatpun tidak ikut berdosa mengamalkan apa yang sudah disampaikan.

Alhamdulillah mayoritas mubaligh di tiga mesjid ini khususnya sudah menyampaikan hadis-hadis yang berkualitas maqbul. Minoritas dari mereka masih ada yang menyampaikan hadis hadis yang berkualitas mardud atau ditolak. Wallahu a'lam bi al-shawab.

\section{Daftar Pustaka}

'Ajjaj al-Khatib, Ushul al-Hadis 'Ulumuh wa Musthalahuh, Beirut: Daar al-Fikr, 1975, cet. Ke-III

\footnotetext{
${ }^{14} \mathrm{HR}$. Muslim di dalam Muqaddimah dan HR. Al-Bukhâri, no. 1229

${ }^{15} \mathrm{HR}$. Al-Bukhâri, no. 106 dan Muslim, no. 1

${ }^{16} \mathrm{HR}$. Muslim di dalam Muqaddimah
} 
Abu Al-Abbas Syihabuddin Ahmad bin Muhammad al-Qasthalaniy, Syarah Shabih BukhariyI, Beirut: Dar al-Fikr, t.th, jilid 6

Abu Muhammad bin Abdul Mahdiy bin Abdul Qadir bin Abdil Hadiy, Thuruq takhrij badis Rasulillah $S A W$, Daar al-I'tisham, t.th.

Adrika Fitrotul Aini, Living Hadis dalam Tradisi malam Kamis Majlis Shalawat Diba' bil Mustofa, Pascasarjana UIN Sunana Kalijaga Yogyakarta, hlm.pendahuluan.

Adrika Fitrotul Aini, Living Hadis dalam Tradisi malam Kamis Majlis Shalawat Diba' bil Mustofa, Pascasarjana UIN Sunana Kalijaga Yogyakarta, hlm.pendahuluan.

Ahmad bin 'Aliy al-Khatib al-baghdadiy, Al-Kifayah fiy Ilm al-Riwayah, India: t.p., 1357 H.

Ahmad bin Hanbal, Musnad Imam Abmad bin Hanbal, Jilid 2.

Ensiklopedia Hadis al-kutub al-sittahShahih Bukhariy jilid 2, nomor hadis 6409, lihat juga Kitab Jami' al-Tirmiziy, nomor hadis 3374.

Ensiklopedia Hadis al-kutub al-sittahShahih Muslim jilid 1, nomor hadis 2031.

Ensiklopedia Hadis al-kutub al-sittahShahih Muslim jilid 2, nomor hadis 6805

Hadits ini didhaifkan oleh para pakar hadits seperti Al 'Aini dalam 'Umdatul Qari (10/383), Al Mundziri dalam At Targhib Wat Tarbib (2/115), Al Albani dalam Takbrij AlMisykah (1906), juga didhaifkan oleh Syaikh Ali Hasan Al Halabi di Sifatu Shaumin Nabiy (110).

Helfina Rayya, Living Hadis dalam Tradisi Haul Guru Sekumpul, mini riset.

Helfina Rayya, Living Hadis dalam Tradisi Haul Guru Sekumpul, mini riset.

Ibn Shalah, 'Ulum Al-Hadis, Medinah; Maktabah al-Ilmiyyah, 1981

Ibnu al-Jauziy, Almaudhun'at nomor 605

Ibnu Qayyim al-Jauziyyah, Manaarul Muniif, hlm. 55-105

Ibrahim Ibn Muhammad, Al-Bayan wa al-Ta'riffiy Asbab Wurud al-Hadis, t. tp, Holb, 1329 $\mathrm{H}$, jilid 3 .

Imam 'Allamah Jamal al-Din Abi al-Fadl Muhammad bin Mukram bin Manzur alAnshariy, Lisan al-Arab, Beirut: Dar al-Kutub al-Ilmiah, 2009, jilid 2.

Luthfi Fathullah, Hadits-hadits Lemah dan Palsu dalam Kitab Durrotun Nashibiin,

M. Alfatih Suryadilaga, Implementasi Pendekatan Integrasi-Interkoneksi dalam kajian living hadis, dalam Islamic Studies; Paradigma- integrasi interkoneksi (Sebuah Antologi) Yogyakarta: Suka Press, 2007.

M. Syuhudi Ismail, Metodologi Penelitian Hadis Nabi, Jakarta: Bulan Bintang, 1992.

M.Syuhudi Ismail, Kaidah Kesahihan Sanad Hadis. Jakarta: Bulan Bintang, 1998 
58 |Jurnal Dakwah dan Komunikasi, Vol. 3, No. 1, 2018

Mahmud at-Tahhan, Ushul al-Takbrij wa Dirasatil Asanid, Halb: Al-Mathbaah al'Arabiyyah, 1398 H/ 1678 M.

Muhammad Fuad Abdul Baqi, Fathul Bariy, jilid 4.

Muhammad Nashiruddin Albani, Silsilab Hadis Dha'if dan Maudhu'Judul Kitab Asli : Silsilatul-Ahaadiits adh-Dhaifah wal-Maudhu'ah wa Atsaruhas-Sayyi' fil-Ummah Penerjemah : Drs. As'ad Yasin, Gema Insani.

Munawwir, A.W. dan Muhammad Fairuz, "Kamus al-Munawwir Indonesia-Arab Terlengkap, Surabaya: Pustaka Progressif, 2007.

Musthafa Ali Yaqub, Hadits-Hadits Palsu Seputar Ramadhan, dan Ahmad Luthfi Fathullah, Hadits-Hadits Lemah Palsu Dalam Kitab Durratun Nasibin.

Sahiron Syamsuddin editor, Metodologi Penelitian Living Quran Hadis, Yogyakarta: TH Press, 2007

Sahiron Syamsuddin editor, Metodologi Penelitian Living Quran Hadis, Yogyakarta: TH Press, 2007

Sahiron Syamsuddin, Metodologi Penelitian Living Quran Hadis, Yogyakarta: TH Press, 2007

Salahuddin bin Ahmad al-Adlabiy, Manhaj Naqd al-Matn, Daar al-Afaq al-Jadidah: Beirut, 1403 H, /1983 M.

Salahuddin bin Ahmad al-Adlabiy, Manhaj Naqd al-Matn, Daar al-Afaq al-Jadidah: Beirut, $1403 \mathrm{H}, / 1983 \mathrm{M}$.

Syamsul Kurniawan, Hadis Jampi-Jampi dalam Kitab Mujarrabat Melayu dan Tajal-Muluk menurut Pandangan Masyarakat Kampung Seberang Kota Pontianak Propinsi Kalimantan Barat, Skripsi UIN Sunan Kalijaga Yogyakarta, 2005

Syamsul Kurniawan, Hadis Jampi-Jampi dalam Kitab Mujarrabat Melayu dan Tajal-Muluk menurut Pandangan Masyarakat Kampung Seberang Kota Pontianak. Propinsi Kalimantan Barat, Skripsi UIN Sunan Kalijaga Yogyakarta, 2005.

Yusuf Qardhawiy, Kaifa nataammalu Sunnah an-Nabawiyyah as-Shabihab, terjemahan Muhammad al-Baqir, Bagaimana Memahami Hadis Nabi SAW.,) selanjutnya disebut Yusuf al-Qardhawiy, (Bandung: Kharisma, 1993).

Zakariya bin Ghulam Qadir al-Bakistani. Hadis-hadis Lemah dan Palsu dlam Ibadah. Jakarta:Darus Sunnah. 2014.

Zuhdi Rifa'i, Mengenal Ilmu Hadis, Al-Ghuraba, 2008 